\title{
Efforts to Improve Teacher Creativity Through Online Learning Models During the Covid-19 Pandemic at SD Negeri 2 Rempe
}

\section{Upaya Peningkatan Kreatifitas Guru Melalui Model Pembelajaran Daring Pada Masa Pandemi Covid-19 di SD Negeri 2 Rempe}

\author{
Mukhsen \\ doi: https://doi.org/10.51518/lentera.v3i2.46
}

email: cenkabank@gmail.com

Guru pada SD Negeri 2 Rempe - Kab. Sumbawa Barat

\begin{abstract}
This study aims to determine the online learning model in increasing the creativity and initiative of teachers in managing learning at home at SD Negeri 2 Rempe. The type of research conducted is school action research (PTS) using Elliot's model. The research was held at SD Negeri 2 Rempe in the 2019/2020 school year during the Covsid 19 pandemic. The research subjects were grade 1, 2, 3, 4, and Grade 5 teachers. The object of the research was learning at home through online learning during the pandemic. covid-19. Data collection is through observation and documentation and then analyzed qualitatively. Based on the results of the study, it shows that the online learning model can overcome and be a solution in implementing learning during the COVID-19 pandemic by involving the creativity and initiative of teachers to manage to learn at home. The creativity and initiative of teachers have increased in making lesson plans by $18 \%$, online learning management by $12 \%$, student activity by $17 \%$, and student learning scores by $9.6 \%$ from cycle I to cycle II in learning. .
\end{abstract}

Keywords: Online Learning, Creativity, Covid-19

Abstrak: Penelitian ini bertujuan untuk mengetahui model pembelajaran daring dalam meningkatkan kreatifitas dan inisiatif guru dalam mengelola pembelajaran di rumah di SD Negeri 2 Rempe. Jenis penelitian yang dilakukan yaitu penelitian tindakan sekolah (PTS) dengan menggunakan model dari Elliot. Penelitian diadakan di SD Negeri 2 Rempe pada tahun pelajaran 2019/2020 di masa pandemi Covid 19. Subjek penelitian adalah guru kelas $1,2,3$, 4, dan guru kelas 5 . Obyek penelitian adalah pembelajaran di rumah melalui pembelajaran daring/online dimasa pademi covid-19. Pengumpulan data yaitu melalui observasi dan dokumentasi kemudian dianalisis secara kualitatif. Berdasarkan hasil penelitian menunjukkan model 
pembelajaran daring dapat mengatasi dan menjadi solusi dalam pelaksanaan pembelajaran dimasa pademi covid-19 dengan melibatkan kreatifitas dan inisiatif guru untuk mengelola pembelajaran di rumah. Kreatifitas dan inisiatif guru mengalami peningkatan dalam pembuatan RPP sebesar $18 \%$, pengelolaan pembelajaran daring sebesar $12 \%$, keaktifan siswa sebesar $17 \%$ dan nilai belajar siswa sebesar $9,6 \%$ dari siklus I ke siklus II dalam pembelajaran.

Kata Kunci: Kreatifitas, Pembelajaran Daring, Covid-19

\section{A. PENDAhUluan}

Pada tanggal 11 Maret 2020 WHO telah mengumumkan status pandemi global untuk virus corona 2019 atau juga disebut Corona Virus Disease 2019 atau Covid 19 Wabah atau penyakit ini telah menyerang banyak korban, serempak di berbagai negara. WHO menetapkan seluruh warga dunia bisa berpotensi terkena infeksi Covid 19, guru dan siswa juga bisa terinfeksi Covid 19. Pemerintah mengambil kebijakan agar anak belajar di rumah. Hal ini diatur dalam UU No. 6 Tahun 2018 tentang Kekarantinaan

Pemerintah memberikan kebijakan agar anak belajar di rumah. Pembelajaran yang dilaksanakan dirumah membuat para orang tua tenang, dikarenakan anak tidak berinteraksi dengan orang lain dan lingkungan luar, agar dapat meminimalisir penyebaran covid-19. Namun, tidak sedikit anak dan juga guru yang kurang dapat memaksimalkan proses pembelajaran dengan menggunakan teknologi, sehingga proses pembelajaran tidak begitu efektif dan efisen.

Dalam Undang-Undang RI Nomr 20 tahun 2003, tentang Sistem Pendidikan Nasional Bab XI Pasal 39 ayat (1), dijelaskan tenaga kependidikan bertugas melaksanakan administrasi, pengelolaan, pengembangan dan pelayanan teknis untuk menunjang proses pendidikan dan satuan pendidikan Menurut pernyataan diatas guru bertugas melaksanakan pengelolaan, pengembangan dan pelayanan teknis untuk menunjang proses pendidikan dalam satuan pendidikan, dari hasil Penulis di Sekolah Dasar masih ada guru yang belum mampu menerapkan pembelajaran dirumah melalui online dikarenakan keterbatasan dalam teknologi, Kondisi tersebut terjadi hampir disebagian besar guru di Sekolah Dasar masih banyak guru yang menerapkan model pembelajaran dengan tugas banyak tanpa memperhatikan situasi dan kondisi dimasa wabah covid-19 ini, harusnya anak dibuat senang agar imun atau daya tahan tubuh pada anak bisa terjaga dengan baik, jangan pembelajaran hanya monoton dan dengan menggunakan model pembelajaran yang kreatif menyenangkan dan tidak membosankan anak, karakter dan kreatif anak harus terus kita bina. Pemberian materi yang terlalu banyak dan melelahkan anak membuat anak kehilangan selera belajar. 
Desain pembelajaran sebagai proses menurut Syaiful Sagala (2006) adalah pengembangan pengajaran secara sistematik yang digunakan secara khusus teori-teori pembelajaran unuk menjamin kualitas pembelajaran. Mengandung arti bahwa penyusunan perencanaan pembelajaran harus sesuai dengan konsep pendidikan dan pembelajaran yang dianut dalam kurikulum yang digunakan.

Desain pembelajaran dapat dimaknai dari berbagai sudut pandang, misalnya sebagai disiplin, sebagai ilmu, sebagai sistem, dan sebagai proses. Sebagai disiplin, desain pembelajaran membahas berbagai penelitian dan teori tentang strategi serta proses pengembangan pembelajaran dan pelaksanaannya. Sebagai ilmu, desain pembelajaran merupakan ilmu untuk menciptakan spesifikasi pengembangan, pelaksanaan, penilaian, serta pengelolaan situasi yang memberikan fasilitas pelayanan pembelajaran dalam skala makro dan mikro untuk berbagai mata pelajaran pada berbagai tingkatan kompleksitas. Sebagai sistem, desain pembelajaran merupakan pengembangan sistem pembelajaran dan sistem pelaksanaannya termasuk sarana serta prosedur untuk meningkatkan mutu belajar (Reza Noprial Lubis:2018).

Teori subtantif yang digunakan dalam riset ini adalah Project Based Learning (Jones, Rasmussen dan Moffit, 1997). Kontribusi teori dalam riset ini antara lain: (1) membantu guru dalam menggunakan berbagai aplikasi pembelajaran daring yang dapat digunakan dalam pembelajaran pada masa pandemi Covid-19, (2) mengukur kemampuan guru dan mengukur efektivitas penggunaan berbagai aplikasi pembelajaran daring yang digunakan dalam pembelajaran pada masa pandemi Covid-19.

Sistem pembelajaran dalam jaringan (daring) ialah sistem pembelajaran dimana guru dan siswa tidak saling bertatap muka dengan menggunakan suatu aplikasi dan jaringan internet. Guru harus memastikan kegiatan belajar mengajar tetap berjalan, meskipun siswa berada di rumah. Solusinya, guru harus dapat memnfaatkan media pembelajaran daring (online). Hal ini sesuai dengan Menteri Pendidikan dan Kebudayaan Republik Indonesia terkait Surat Edaran Nomor 4 Tahun 2020 tentang Pelaksanaan Kebijakan Pendidikan dalam Masa Darurat Penyebaran Corona Virus Disease (COVID-19) yang menganjurkan seluruh kegiatan di institusi pendidikan harus jaga jarak dan seluruh penyampaian materi akan disampaikan di rumah masing-masing.

Keberhasilan guru dalam melakukan pembelajaran daring pada situasi pandemi Covid-19 ini adalah kemampuan guru dalam berinovasi merancang, dan meramu materi, metode pembelajaran, dan aplikasi apa yang sesuai dengan materi dan metode. Kreatifitas merupakan kunci sukses dari seorang guru untuk dapat memotivasi siswanya tetap semangat dalam belajar secara daring (online) dan tidak menjadi beban psikis.

Di samping itu, kesuksesan pembelajaran daring selama masa Covid- 19 ini tergantung pada kedisiplinan semua pihak. Oleh karena itu, 
pihak sekolah perlu menyusun skema yang baik dalam mengatur sistem pembelajarannya. Hal ini dapat dilakukan dengan membuat dan menyusun jadwal yang sistematis, terstruktur dan simpel untuk memudahkan komunikasi orangtua dengan sekolah agar putra- putrinya yang belajar di rumah dapat terpantau secara efektif.

Dengan demikian, pembelajaran daring sebagai solusi yang efektif dalam pembelajaran di rumah guna memutus mata rantai penyebaran Covid- 19, physical distancing (menjaga jarak aman) juga menjadi pertimbangan dipilihnya pembelajaran tersebut. Kerjasama yang baik antara guru, siswa, orangtua siswa dan pihak sekolah/madrasah menjadi faktor penentu agar pembelajaran daring lebih efektif.

\section{B. METODE PENELITIAN}

Penelitian tindakan sekolah ini menggunakan model siklus dari Elliot, setiap siklus terdiri atas empat tahap kegiatan yaitu: the planning of the action (rencana tindakan), the implementation of the action (implementasi tindakan), classroom observation (observasi kelas), dan the reflection of the action (refleksi tindakan). Tindakan yang diterapkan pada subjek dalam penelitian ini adalah meningkatkan kemampuan mengelola pembelajaran BDR melalui model daring.

Penelitian ini dilaksanakan dalam 2 siklus dimana setiap siklus terdiri dari 4 tahapan yaitu: (1) the planning of the action (perencanaan), (2) the implementation of the action (implementasi tindakan), (3) class observation or monitoring and evaluation (observasi kelas dan evaluasi), (4) data analysis and reflection of the action (analisis data dan refleksi tindakan).

\section{HASIL DAN PEMBAHASAN}

Prasiklus kondisi pembelajaran masa pandemi covid-19 melalui daring/online pada pra siklus masih konvensional. Kemampuan guru dalam melaksanakan pembalajaran BDR masih rendah, hal ini dapat dilihat dari suasana pembelajaran BDR melalui daring yang kurang kondusif, aktifitas siswa yang kurang terkontrol, minat siswa dalam belajar kurang, siswa tidak semangat dalam melaksanakan kegiatan pembelajaran BDR, kurang motivasi, sehingga berdampak pada rendahnya nilai belajar siswa. Data hasil supervisi akademik pada prasiklus terangkum pada tabel berikut

Tabel 1

Rangkuman hasil supervisi akademik dalam masa pademi covid-19 Pra Siklus

\begin{tabular}{lcc}
\hline \multicolumn{1}{c}{ Item } & $\begin{array}{c}\text { Nilai Rata- } \\
\text { rata } \\
\text { supervisi }\end{array}$ & $\begin{array}{c}\text { Indikator } \\
\text { keberhasilan }\end{array}$ \\
\hline Kreatifitas dalam Penyusunan RPP & $72 \%$ & $85 \%$ \\
\hline $\begin{array}{l}\text { Inisiatif Pengelolaan Pembelajaran } \\
\text { Daring }\end{array}$ & $72 \%$ & $85 \%$ \\
\hline
\end{tabular}




\begin{tabular}{lll}
\hline Keaktifan Siswa & $69 \%$ & $85 \%$ \\
\hline Nilai Siswa & $69 \%$ & $75 \%$ \\
\hline
\end{tabular}

Pada Tabel 1 memberikan gambaran bahwa kompetensi guru dalam membuat RPP, pemberian tugas daring, keaktifan siswa masih jauh di bawah indikator keberhasilan. Kenyataan tersebut terjadi karena kompetensi guru di bidang pembelajaran BDR masih rendah. Proses pembelajaran cenderung menyampaikan materi kepada siswa. Pengelolaan kelas tidak optimal, perhatian terhadap siswa kurang menyeluruh.

Penelitian Tindakan Sekolah pada siklus I dilaksanakan pada bulan Oktober 2020. Kegiatan Siklus I meliputi perencanaan, implementasi tindakan, observasi, dan analisis data serta refleksi tindakan. Kegiatan yang dilakukan dalam perencanaan adalah merencanakan pembinaan terhadap guru. Pembinaan dilakukan dengan diskusi, penjelasan tentang pembelajaran BDR melalui daring/online dan merencanakan pemodelan. Peneliti membuat RPP pembinaan terhadap guru, RPP pemodelan, membuat instrument observasi dan menyusun jadwal. Acting mencakup pelaksanaan bimbingan dan pemodelan. Observing berupa mengamati guru dalam pembelajaran daring/online dengan ikut dalam group masing masing kelas pembelajaran dalam menyusun perencanaan dan pelaksanaan proses belajar mengajar melalui daring. Sedangkan reflecting berupa membandingkan kompetensi guru dengan indikator.

Pada tahap pelaksanaan kegiatan ini peneliti melakukan pembinaan tentang pembelajaran BDR melalui daring/online dengan sistem diskusi, penyampaian materi, dan pemberian contoh pembelajaran BDR melalui daring/online. Setelah pembinaan selesai dilakukan, langkah selanjutnya adalah observasi. Observasi dalam daring dilakukan dengan ikut dalam group perkelas dalam pembelajaran daring melalui online dilakukan dengan tujuan untuk mengetahui tingkat partisipasi atau keaktifan siswa dalam proses pembelajaran. Hal ini juga sebagai bentuk evaluasi terhadap proses pembelajaran. Lembar observasi yang digunakan berupa lembar checklist. Indikator yang diamati adalah tingkat partisipasi siswa dalam pengerjaan tugas tugas yang diberikan oleh guru melalui daring/online.

Tabel 2

Rangkuman Analisis Hasil Observasi Siklus I

\begin{tabular}{|c|c|c|c|c|c|c|c|c|}
\hline \multirow{2}{*}{ Item } & \multicolumn{5}{|c|}{ Nilai Observasi Guru (\%) } & \multirow{2}{*}{$\begin{array}{c}\text { Rerata } \\
(\%)\end{array}$} & \multirow{2}{*}{$\begin{array}{l}\text { Indikator } \\
\text { Keberhasil } \\
\text { an (\%) }\end{array}$} & \multirow{2}{*}{$\begin{array}{c}\text { Kesenjang } \\
\text { an (\%) }\end{array}$} \\
\hline & I & II & III & IV & $\mathbf{v}$ & & & \\
\hline $\begin{array}{l}\text { Kreatifitas } \\
\text { dalam } \\
\text { Penyusunan } \\
\text { RPP }\end{array}$ & 67 & 73 & 66 & 74 & 65 & 69 & 85 & 16 \\
\hline
\end{tabular}




\begin{tabular}{|c|c|c|c|c|c|c|c|c|}
\hline $\begin{array}{l}\text { Inisiatif } \\
\text { Pengelolaan } \\
\text { Pembelajaran } \\
\text { Daring }\end{array}$ & 77 & 77 & 74 & 80 & 72 & 76 & 85 & 9 \\
\hline Keaktifan Siswa & 74 & 73 & 73 & 74 & 66 & 71 & 85 & 13 \\
\hline Nilai Siswa & 72 & 70 & 70 & 71 & 69 & 70,4 & 75 & 4,6 \\
\hline
\end{tabular}

Tabel 2 dapat dibaca bahwa hasil observasi RPP terhadap guru kelas 1, guru kelas 2, guru kelas 3, guru kelas 4, dan guru kelas 5 dari kelima guru yang menjadi subjek penelitian mendapat skor $69 \%$. Hasil observasi terhadap pengelolaan kelas mendapat skor $76 \%$. Hasil observasi terhadap keaktifan siswa mendapat skor $72 \%$. Hasil observasi terhadap nilai yang diperoleh siswa mendapat skor $70,4 \%$. Dari kelima item yang diobservasi skor terendah pada kemampuan membuat RPP. Sedangkan perolehan skor tertinggi pada kompetensi pengelolaan kelas yaitu mendapat skor $76 \%$.

Berdasarkan skor capaian kompetensi guru masih lebih rendah dibandingkan dengan indikator keberhasilan. Kompetensi pembuatan RPP mendapatkan skor $69 \%$, sementara indikator keberhasilan $85 \%$. Ini berarti masih ada kesenjangan $7 \%$. Hasil observasi terhadap pengelolaan kelas mendapat skor $76 \%$ dan hasil observasi terhadap keaktifan siswa mendapat skor $71 \%$ sedangkan indikator keberhasilan $85 \%$. Ini berarti masih ada kesenjangan $12 \%$. Hasil observasi terhadap nilai yang diperoleh siswa mendapat skor $70,4 \%$, sementara indikator keberhasilan $75 \%$. Ini berarti masih ada kesenjangan 4,6\%. Oleh karena itu untuk mencapai ketuntasan dilanjutkan dengan siklus II.

Siklus II dilaksanakan pada tanggal November 2020. Pada tahap perencanaan peneliti melaksanakan kegiatan: a) menyusun perencanaan pembinaan terhadap guru, b) menyusun RPP pemodelan, c) menyusun instrumen untuk observasi aktivitas siswa, d) menyusun instrumen untuk observasi pengelolaan pembelajaran BDR oleh guru, dan e) menyusun instrumen untuk observasi RPP guru. Pada pelaksanaan tindakan Siklus II, peneliti melaksanakan pembinaan terhadap guru. Guru dikumpulkan secara berkelompok, dengan mematuhi protokol pemerintah yaitu pakai cuci tangan pakai air yang mengalir, atau hand sanitizer, masker, duduk dengan jarak 1 meter diberi pembinaan. Isi pembinaan berupa bagaimanakah membuat RPP yang lengkap, bagaimana mengelola pembelajaran BDR melalui daring yang baik, menarik, dan dapat mencapai tujuan, serta bagaimana dapat memusatkan perhatian siswa agar antusias dalam mengikuti pelajaran BDR melalui daring agar imun anak tetap terjaga dan juga dengan didampingi oleh orang tua masing-masing.

Observasi pembelajaran BDR melalui daring dilakukan oleh peneliti dan dibantu oleh kolaborator. Kolabulator mengobservasi peneliti dalam membuat RPP pembimbingan, saat peneliti melakukan pembimbingan, RPP KBM model, pengelolaan pembelajaran BDR melalui daring/online saat model mememberikan tugas tugas pembelajaran, dan keterlibatan 
siswa dalam mengikuti pembelajaran daring/online guru model. Peneliti melakukan observasi RPP guru, pengelolaan pembelajaran BDR saat guru memberikan tugas pembelajaran daring, dan keterlibatan siswa dalam mengikuti pembelajaran guru. Observasi dilakukan dengan tujuan untuk mengetahui tingkat partisipasi atau keaktifan siswa dalam proses pembelajaran daring/online. Hal ini juga sebagai bentuk evaluasi terhadap proses pembelajaran. Lembar observasi yang digunakan berupa lembar checklist. Indikator yang diamati adalah tingkat partisipasi siswa dalam proses pembelajaran BDR melalui daring/online.

Tabel 3

Rangkuman Analisis Hasil Observasi Siklus II

\begin{tabular}{|c|c|c|c|c|c|c|c|c|}
\hline \multirow{2}{*}{ Item } & \multicolumn{5}{|c|}{ Nilai Observasi Guru (\%) } & \multirow{2}{*}{$\begin{array}{c}\text { Rerata } \\
(\%)\end{array}$} & \multirow{2}{*}{$\begin{array}{c}\text { Indikator } \\
\text { Keberhasilan } \\
(\%)\end{array}$} & \multirow{2}{*}{ Keterangan } \\
\hline & I & II & III & IV & $\mathbf{v}$ & & & \\
\hline $\begin{array}{l}\text { Kreatifitas dalam } \\
\text { Penyusunan RPP }\end{array}$ & 85 & 88 & 86 & 86 & 86 & 87 & 85 & Tuntas \\
\hline $\begin{array}{l}\text { Inisiatif } \\
\text { Pengelolaan } \\
\text { Pembelajaran } \\
\text { Daring }\end{array}$ & 87 & 90 & 90 & 87 & 85 & 88 & 85 & Tuntas \\
\hline Keaktifan Siswa & 87 & 90 & 85 & 97 & 85 & 88 & 85 & Tuntas \\
\hline Nilai Siswa & 79 & 82 & 78 & 80 & 81 & 80 & 75 & Tuntas \\
\hline
\end{tabular}

Hasil observasi RPP terhadap guru kelas 1, guru kelas 2, guru kelas 3, guru kelas 4, dan guru guru kelas 5 mendapat skor yaitu $87 \%$. Hasil observasi terhadap pengelolaan pembelajaran BDR melalui daring/online mendapat skor $88 \%$. Hasil observasi terhadap keaktifan siswa mendapat skor $88 \%$. Hasil observasi terhadap nilai yang diperoleh siswa mendapat skor $80 \%$. Indikator keberhasilan membuat RPP, Pengelolaan kelas, keterlibatan siswa ditetapkan $85 \%$, sedangan hasil belajar siswa ditetapkan $75 \%$. Perbandingan antara skor capaian dengan indikator keberhasilan menunjukkan adanya peningkatan antara siklus satu dan siklus dua. Bila dibandingkan dengan indikator keberhasilan sudah melampaui indikator keberhasilan atau tuntas.

Tabel 4

Progres Capaian Kompetensi Guru dari Siklus I ke Siklus II

\begin{tabular}{lcccccc}
\hline \multicolumn{1}{c}{ Kompetensi } & $\begin{array}{c}\text { Siklus } \\
\text { I }\end{array}$ & $\begin{array}{c}\text { Siklus } \\
\text { II }\end{array}$ & $\begin{array}{c}\text { Indikator } \\
\text { Keberhasilan }\end{array}$ & \multicolumn{2}{c}{ Keterangan } \\
\hline $\begin{array}{l}\text { Kreatifitas } \\
\text { dalam }\end{array}$ & $69 \%$ & $87 \%$ & $85 \%$ & $\begin{array}{l}\text { Dari siklus I ke } \\
\text { siklus II mengalami } \\
\text { kenaikan } 18 \%\end{array}$ \\
$\begin{array}{l}\text { Penyusunan } \\
\text { RPP }\end{array}$ & & & & & & Dari siklus I ke \\
\hline $\begin{array}{l}\text { Inisiatif } \\
\text { Pengelolaan } \\
\text { Pembelajaran }\end{array}$ & $76 \%$ & $88 \%$ & $85 \%$ & $\begin{array}{l}\text { siklus II mengalami } \\
\text { kenaikan 12 \% }\end{array}$ \\
\hline
\end{tabular}


ISSN Cetak: 2685-5542

\begin{tabular}{lcccl}
\hline Daring & & & & \\
\hline $\begin{array}{l}\text { Keterlibatan } \\
\text { siswa }\end{array}$ & $71 \%$ & $88 \%$ & $85 \%$ & $\begin{array}{l}\text { Dari siklus I ke } \\
\text { siklus II mengalami } \\
\text { kenaikan 17\% }\end{array}$ \\
\hline $\begin{array}{l}\text { Hasil penilaian } \\
\text { siswa }\end{array}$ & $\begin{array}{c}70,4 \\
\%\end{array}$ & $80 \%$ & $75 \%$ & $\begin{array}{l}\text { Dari siklus I ke } \\
\text { siklus II mengalami } \\
\text { kenaikan } 9,6 \%\end{array}$ \\
\hline
\end{tabular}

\section{KESIMPULAN}

Berdasarkan hasil penelitian menunjukkan model pembelajaran daring dapat mengatasi dan menjadi solusi dalam pelaksanaan pembelajaran dimasa pademi covid-19 dengan melibatkan kreatifitas dan inisiatif guru untuk mengelola pembelajaran di rumah. Kreatifitas dan inisiatif guru mengalami peningkatan dalam pembuatan RPP sebesar $18 \%$, pengelolaan pembelajaran daring sebesar $12 \%$, keaktifan siswa sebesar $17 \%$ dan nilai belajar siswa sebesar $9,6 \%$ dari siklus I ke siklus II dalam pembelajaran 


\section{DAFTAR RUJUKAN}

Depdiknas. 2003. UU RI No. 20 Tahun 2003 tentang Sistem Pendidikan Nasional. Jakarta: Depdiknas. 2004. Standar Kompetensi Guru Sekolah Dasar. Jakarta: Depdiknas.

Jones, B. F., Rasmussen, C. M., \& Moffit, M. C. (1997). Real-life problem solving: A collaborative approach to interdisciplinary learning. Washington, DC: American Psychological Association.

Permendiknas No 13 Tahun 2007 yaitu tentang standar kompetensi kepala sekolah madrasah. Jakarta: Depdiknas

PP No. 21 Tahun 2020 tentang Pembatasan Sosial Berskala Besar (PSBB).Jakarta

Syaiful, Sagala. 2003. Konsep dan Makna Pembelajaran. Bandung: Alfabeta.

UU No. 6 Tahun 2018 tentang Kekarantinaan Kesehatan ; Dinkes Jakarta

Reza Noprial Lubis. 2018. Desain Tujuan Pembelajaran. https://rezanopriallubis2018.wordpress.com/2017/11/03/desaintujuan-pembelajaran-oleh-reza-noprial-lubis-s-pd-i. Diakses pada Februari 2021. 
ISSN Cetak: 2685-5542

ISSN Online: 2685-5550

64|Edisi 3 No. 2 Januari-Juli 2021 